\title{
RETAIL CHANNEL SERVICES AND CUSTOMER RETENTION IN PHYSICAL CHAIN STORES IN NIGERIA
}

\section{Oby Blessing Osuagwuํㅜ, Ananaba Ugwunwanyi², Udoka Stephen Otika ${ }^{3}$}

\section{and Samuel Ngozichikanma Nwosu ${ }^{4}$}

${ }^{1}$ Department of Business Administration, Hezekiah University, Umudi, Imo State, Nigeria Email: rhina.201@gmail.com

${ }^{2}$ Department of Industrial Relations and Personnel Management, Michael Okpara University of Agriculture, Umudike. Email: Ananabaug09@yahoo.com

${ }^{3}$ Department of Marketing, Evangel University, Akaeze, Ebonyi State

Email: ud.otika@evangeluniversity.edu.ng

${ }^{4}$ Department of Accounting, Evangel University, Akaeze, Ebonyi State.

Email: samca880@gmail.com

Cite this article:

Oby B.O., Ananaba U., Udoka S.O., Samuel N.N. (2021),

Retail Channel Services and

Customer Retention in

Physical Chain Stores in

Nigeria. International Journal of Entrepreneurship and

Business Innovation 4(1), 96108. DOI: 10.52589/IJEBI5B62AJ4J.

\section{Manuscript History}

Received: 10 Oct 2021

Accepted: 1 Nov 2021

Published: 25 Nov 2021

Copyright $\odot 2020$ The Author(s). This is an Open Access article distributed under the terms of Creative Commons AttributionNonCommercial-NoDerivatives 4.0 International (CC BY-NC-ND 4.0 ), which permits anyone to share, use, reproduce and redistribute in any medium, provided the original author and source are credited.
ABSTRACT: Extant literature indicates that despite the growing importance of retailing to the development of nations, it is imperative to ask; to what extent does retail channel service relates to customer retention in chain stores in Nigeria. The main objective of the study is to examine the significant relationship between retail channel service and customer retention in chain stores in Nigeria. The study adopted a quantitative research design using a survey method. The study population comprised 65 retail chain stores registered with the Enugu Branch of Pillars Association of Nigeria as of July 2020. The questionnaires were pretested for comprehension, relevance and validity through ten operators of retail superstores and three scholars in the field of distribution channel management. The reliability of the instrument was tested using Cronbach's alpha coefficient analysis in order to ensure the internal consistency and reliability of measures. The reliability coefficient obtained was 0.85 . The findings of the study show that bulk breaking, spatial convenience, waiting time and product variety are positively related to customer retention. We conclude that retail channel service has a positive and significant influence on customer retention of retail chain stores in Nigeria. The retail chain stores, if effectively coordinated, and their marketing channel service properly managed, is capable of enhancing the tendencies of these retail stores in retaining their existing customers.

KEYWORDS: Retail Channel Services, Bulk-Breaking, Spatial Convenience, Waiting Time, Product Variety, Customer Retention 


\section{INTRODUCTION}

Retail business in Nigeria is largely informal and fragmented. Informal retailing is growing faster in number and investment largely because of the seeming reluctance of the populace to change from the traditional ways of trading and partly because of a growing number of unemployed youths taking to retailing as a means of survival. Consequently, Retailing has remained one of the easiest ways to be gainfully employed. However, in recent decades the Nigerian economy has been experiencing increasing relevance of formal retailing (departmental retail shops, chain stores and supermarkets). This can be inferred from several retail outlets coming into the competitive retail market including foreign retail outlets. Several retail outlets had sprung up in the last decade especially after the failure of departmental stores in the 1960s and 1970s. Today there are various types of retail outlets, some of which are specialized outlets; general outlets (most of whom are chain stores) about a quarter of them are foreign retail stores.

Today, Nigeria is experiencing a tremendous shift to a more sophisticated structure as formal or organized retail continues to gain ascendency. The distribution chain and the organization of outlets continue to reflect those of a rapidly evolving economy as standards of living improve and as the population continues to snowball. In the past eight years, Nigeria's population has grown from 150 million, as established by the population census conducted in 2006, to a country with an estimated population of 200 million people by 2021. In the midst of this, the middle class continues to expand even as 51 per cent of the country's population now lives in cities. The rise of organized retailing has been rapid in Nigeria in the last two decades. NBS data shows that between 2001 and 2004, the wholesale and retail sector grew by 10 per cent per annum. By 2006, its contribution was 16 per cent. In the first halves of 2011, 2012 and 2013, it contributed 15.58 per cent, 17.05 per cent and 18.44 per cent of GDP respectively. Chain stores are two or more outlets that are commonly owned, managed and controlled by one person or group of persons (Kotler and Armstrong, 2010). Retail chain stores in Nigeria and other developing nations are growing faster in number as a result of the increase in minimum wage across the nation, increase in employment among parents, the emergence of the middle class in the Nigerian society, increasing urbanization, an increasing number of women in the labour force (Oyeniyi and Abiodun, 2012; Rana, Osman and Islam, 2014) and lifestyle dynamics of consumers taste and shopping preference also contributed to the growth of retail chain stores in Nigeria and other developing economies. As such, chain outlets in Nigeria are adopting a more consumer-oriented strategy that would help to attract customers and retain them as well in order to gain a competitive advantage.

In today's contemporary and competitive business world, customer retention strategy focused on satisfying and preserving the customer in order not to be taken over by competitors. The chain store business is so competitive and dynamic in the sense that competitors are looking out for ways to capture customers from another company by providing value-added services in a unique way. This has reinvigorated the need for a more robust customer retention strategy in chain stores to facilitate business performance. One of the key challenges is how retail chain stores can manage the effective implementation of customer retention strategy which holds strongly to business performance. Perhaps, over the years, there has been a high rate of liquidation or closure of supermarkets and chain stores in most Nigerian cities (Ezenwanne, 2005). This is caused by poor management and the inability to initiate robust customer retention strategies that would help to leverage business performance. Under this condition, the defection rate of existing customers becomes imminent, by losing a significant number of buyers to 
competitors that impact major support to organizational profitability and growth, which is quite worrisome. The essence of the customer retention strategy is to address these problems by striving to retain customers that will be devoted to the retail firms due to the benefit attached to customers who are committed (Ghavami and Olyaei, 2006).

\section{Statement of the Problem}

Retailing is identified as one of the top contributors for the service sector worldwide (Currah and Wrigley, 2004; Kaliappan et al., 2008) which constantly evolves over time. The emergence of retailing in Nigeria has more to do with the increasing purchasing power of buyers. An increase in product variety and increase in economies of scale with the aid of modern supply and distributions solution gave way for these new trends. Retailing today is at an interesting crossroads. It is believed that customer retention strategy will be a vital management tool for retailers to survive and grow in the very competitive sector as retailers encounter fierce competition both from local and foreign retailers alike and as well as from non-traditional retailers such as online retailers (Levy, 2009). A review of past literature indicates that studies on customer retention concentrated more on the manufacturing sector over the service (retailing) sector (Anderson and Sullivan, 1993) despite its growing importance to the development of nations (Hernandez, 2004; Ganz, 2005). Based on the foregoing, it is imperative to ask; to what extent does retail channel service relates to customer retention in chain stores in Nigeria? The answer to the question is the basic justification of this study and it would contribute immensely to the growing literature in the retail chain stores in Nigeria and possibly bridge the gap. It should be noted that retailing has been one of the most dynamic subsectors in the Nigerian economy, which endured constant transformation over the years (Mui et al., 2003).

\section{Objective of the Study}

The main objective of the study is to examine the significant relationship between retail channel service and customer retention in chain stores in Nigeria. Specifically, the study seeks to;

1. Investigate the significant relationship between bulk-breaking and customer retention in chain stores in Nigeria.

2. Examine the significant relationship between spatial and customer retention in chain stores in Nigeria.

3. Ascertain the significant relationship between waiting time and customer retention in chain stores in Nigeria.

4. Examine the significant relationship between product variety and customer retention in chain stores in Nigeria. 


\section{REVIEW OF RELATED LITERATURE}

\section{Retail Channel Service}

Retailing is a socio-economic system, which brings people together, to exchange goods and services for a small consideration; which matches the needs of people, the ultimate consumers, with those of manufacturers and agriculturists, which not only satisfies the essential daily necessities of life but also promotes new lifestyles, thus peace, happiness and prosperity in the community (Rudrabasavaraj, 2010). The origin of the retail word comes from the French "retailer" which means "to cut a piece off" or "to break bulk". In other words, it shows a firsthand transaction with the customer (Dhotre, 2010; Amit \& Kameshvari, 2012). Amit \& Kameshvari define retailing as a group of activities where goods and services are marketed to final consumers for personal or household consumption. Retailing does this by making them available to a massive extent and offering them to consumers to a relatively small extent. In a similar meaning, Kotler and Armstrong (2012) define retailing as all the activities for selling goods or services directly to ultimate buyers for their personal, non-business use. According to Aydin (2013), retailing represents the entirety of activities that add value to products and services sold to consumers for personal use and households. So, retailing consists of all of the activities of goods sold to ultimate buyers (Perreault et al., 2013). Retailing thus is seen as the ultimate gate in the delivery of products, for consumption by the final consumers. Any firm that markets goods to the ultimate buyer is doing the function of retailing. It thus includes all activities associated with the selling of products and services directly to the buyers, for their personal, family or household use. Retail is the final stage of any economic activity (Arora, 2012). People or businesses who deal with retailing are called retailers. Brokers who participate in carrying out a retail activity in the marketing channel are persons or businesses who have retailing as a profession. (Aydin et al., 2013). Many entities; producers, wholesalers, and retailers, perform retailing. But the largest part of retailing is performed by retailers, businesses whose sales come mainly from retailing (Kotler and Armstrong, 2012). Even if almost all businesses; manufacturers, wholesalers, and retailers sell goods to the latest consumers, retailing is mostly performed by retailers because that's their job (Mucuk, 2009). Thus, the customer and the fulfilment of customer desires and needs which are the key points of retailing are the retailing focus (MEGEP, 2008).

\section{Customer Retention}

When discussing customer retention, different explanations or concepts are introduced with the intention of identifying, categorizing and establishing what the necessary factors that constitute customer retention are (Grönroos, 1990; Buttle, 2001). However, the perspective that customer retention is more profitable and delivers more value for business has grown (Berry and Parasuraman, 1992; Peck et al., 1999) and is still much prevalent in contemporary business literature (Rahman and Masoom, 2012). There are numerous studies in the marketing literature especially service literature on customer retention and its various antecedents, (Rajayogon, \& Muthumani, 2015; Julian; Ahmed; Wei \& Bojei, 2016). Ahmad and Buttle (2001) summarize in their article that customer retention is whenever a customer does not leave or switch to other competitors. Customer retention strategy is the marketing-oriented goal that prevents customers from competitors (Ramakrishnan, 2006). According to Mostert et al (2009) asserts that it is a strategy aimed at sustaining existing customers to stay with the company in the established time. We can say that customer retention strategies are action plans geared towards 
International Journal of Entrepreneurship and Business Innovation

ISSN: 2689-9493

Volume 4, Issue 1, 2021 (pp. 96-108)

www.abjournals.org

creating value for customers by encouraging them to be loyal customers with the company over time.

Dawkins and Reichheld (1990) were the first to publish the actual tangible effects of customer retention in the form of higher profitability. Although the benefits of customer retention differed depending on which industry was looked at (Payne and Frow, 1999), the main idea was that acquiring customers costs more than retaining existing customers (Reichheld and Kenny, 1990; Gallo, 2014). The acquisition cost, however, always declined the longer a customer stayed as a customer due to recurring revenues (Ibid.). Even from a value-derived perspective, customer retention has been proven to provide more long term value for the business rather than the initial acquisition (Vandermerwe, 1996). This value could be in the form of marketing and attracting new customers as well as promote beneficial partnerships that could lead to increased market share etc. (Ibid.) Bloemer and Kasper (2014) found in their research that there is a direct link between the level of customer satisfaction and whether or not customers defect or stay.

\section{Retail Channel service and customer retention}

Marketing efforts directed at retaining customers must take into consideration identification of the types and levels of services that customers desire and are willing to pay for (Jayaran et al, 2008). Considering retail channels from the perspective of added values in the channel, we tend to think of issues such as speed of delivery, reliability of delivery, ease of purchase as customers convenience. Through channel service, organizations create a reputation that assures customers that they can be treated as truly valued customers and thereby enhancing chances of retaining customers which in turn guarantees the success of organizations (Lynch, 2006). Organizations, including retails chain stores are greatly focusing on customers in order to increase their profit level through an increase in sales. Oliver (1997) argued that activities directed at retaining customers will result in benefits such as low customer defection, repeat purchase, referrals, cross-selling etc. To this end, firms employ various marketing activities to improve their customer retention goals. Customers value quick delivery, full assortment, bulk-breaking and spatial convenience (Ozuem et al, 2008). It is proposed in this study that through channel service outputs, retail chain stores are likely to experience improved customer retention.

\section{Bulk-Breaking and Customer Retention}

Bulk-breaking refers to the ability of customers to buy the desired number of units of a product or service even though they may be originally produced in large sizes (Bucklin, 2004). When a marketing channel system allows the customer to buy in small lot sizes, purchases can more easily move into consumption, thereby reducing the need to carry unnecessary inventory. The more bulk-breaking a channel system does, the smaller the lot size consumers can buy and the higher the channel's service outputs level. From the customer's perspective, it is obvious that the more bulk-breaking, the less need for customers to carry inventory. This will enhance customer satisfaction which is related to customer retention rate where more satisfied customers stay longer with a firm (Reinartz and Kumar, 2003). Arguably, through bulkbreaking, retail outfits are likely to secure customer loyalty which implies customer willingness to constantly patronize such firms. We hypothesis that;

Hol: there is no significant relationship between bulk-breaking and customer retention in retail chain stores 


\section{Spatial Convenience and Customer Retention}

Greater spatial convenience increases customer satisfaction by reducing transportation and search costs. Spatial convenience relates to market decentralization of retail outlets which increases customers satisfaction by reducing transportation and search costs (Bucklin, 2004). Retail outfits such as community shopping centres, neighbourhood supermarkets, convenience stores etc are few examples of channel forms designed to satisfy consumers' demands for spatial convenience. Convenience is a major consideration for customer satisfaction (Kim et al, 2004). It is likely that retained customers tend to have higher levels of satisfaction to the extent that they see no reason to switch or defect to competitors.

Ho2: there is no significant relationship between spatial convenience and customer retention

\section{Waiting Time and Customer Retention}

According to Bucklin (2004). Waiting time is the time period that the end-user (consumer) must wait between ordering and receiving goods. The longer the waiting time, the more inconvenience it is for the end-user. This implies that quick delivery is highly valued by customers. Therefore, customers will be willing to patronize retail chain stores that maintain quick delivery. This will no doubt, boost customer retention in such firms.

Ноз: there is no significant relationship between waiting time and customer retention in retail chain stores.

\section{Product Variety and Customers Retention}

It is believed that the wider the breadth of assortment or the greater the product variety available to the end-user, the higher the service outputs of the marketing channel system (Buckling, 2004). Greater assortment entails carrying more inventories, thereby making it easier for end-users to engage in one-stop shopping which will save customers the cost and inconveniences associated with moving from one shop location to another. Arguably, through product variety, retail superstores stand the chance of retaining their customers.

Ho4: there is no significant relationship between product variety and customer retention in retail chain stores.

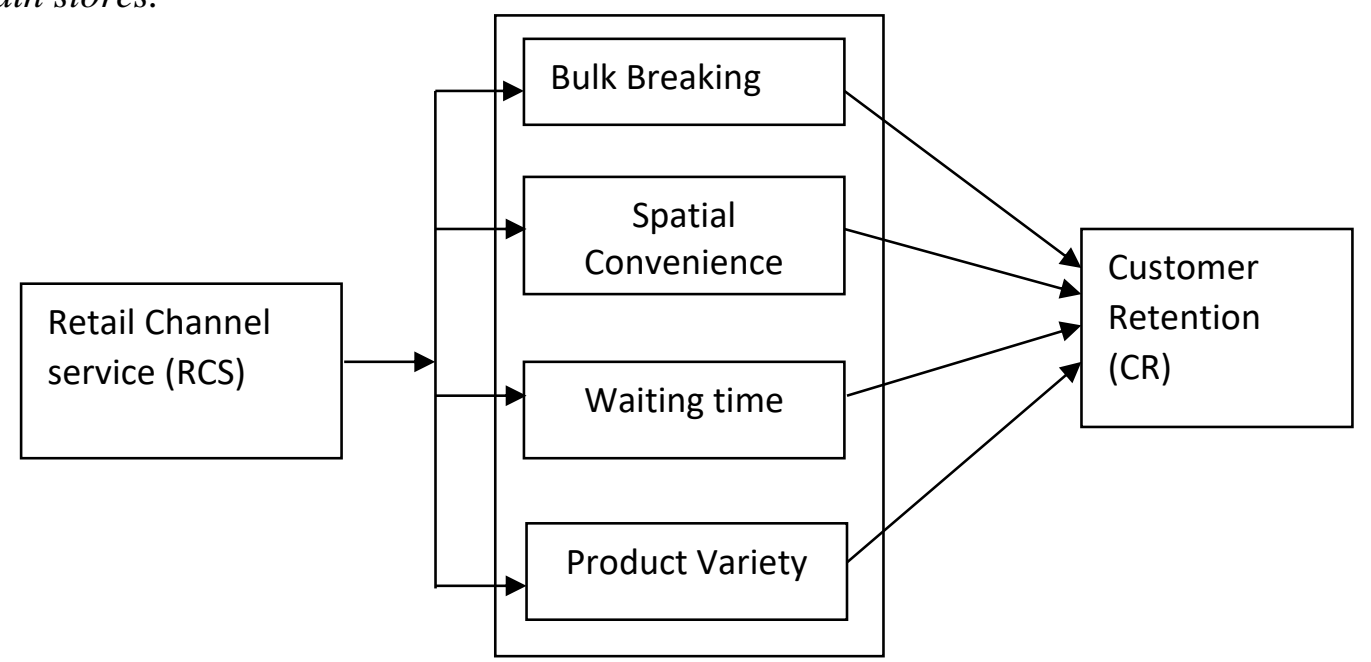

Figure 1: study framework showing the relationship between dimensions of retail channel service and customer retention.

Source: Researchers Conceptualization (2021) 


\section{Theoretical Review}

\section{Customer Value-Based Theory}

The theoretical underpinning of this study is rooted from the work of Slater (1997) on the customer value-based theory of firms. The theory states that the organization should strive to understand what the customer wants, provide it, surpass customer expectations and stand out in the market. The creation of customer value must be the ultimate justification for the firms' existence and success. The increasing complexity and competitive environment facing the chain stores in Nigeria requires chain outlets owners to map out better strategies that will retain their customers, so as to increase performance in the long run. These performances can only be attained if organizations are willing to create value in the products they sell or services rendered to customers. Slater (1997) argues that when customers demand a product it depends on the service quality firms provide for buyers. Customer satisfaction can be achieved when superior customer values are delivered by the organization. Slater further argues that the greater performance of any business is the result of providing superior customer values; better performance enables firms to possess a competitive advantage. The strategies to be adopted by retail chain stores that will enhance better performance solidly rest on the perceived value customers attach to the products or services.

\section{Method}

This study adopted a quantitative research design using a survey method. The study population comprised 65 retail chain stores registered with the Enugu Branch of Pillars Association of Nigeria as of July 2020. The sample size consisted of 56 retail chain stores based on Krejcie and Morgan (1970) table for determining the sample size of a given population as quoted by Sekaran (2003). The table simply requires matching a given population to the corresponding sample size to arrive at an adequate sample size for research work. A total of 168 subjects made up of owners, senior managers and marketing executives in the frame of three (3) respondents from each firm were surveyed through questionnaire administration. The questionnaire was divided into three sections involving questions relating to respondents demographics, questions relating to retail channel service dimensions and questions relating to customer retention. These questions were pretested for comprehension, relevance and validity through ten operators of retail superstores and three scholars in the field of distribution channel management. The pilot survey participants were asked to identify possible problems as touching the content of the questionnaire and their response formed the basis for improving response rate of $80.36 \%$ representing 135 useable copies of the questionnaire were obtained and formed the bases for analysis.

The items that were used to measure the variables in this study were based on theory and largely drawn from relevant literature. Data on the retail channel service dimensions and customer retention were captured on a five-point Likert Scale with 1 depicting "strongly disagree" and 5 depicting "strongly agree". Specifically, the independent variable-retail channel service (RCS) was measured in terms of bulk-breaking, spatial convenience, waiting time and product variety as adapted from Bucklin (2004). A subjective approach was adopted to measure the dependent variable-customer retention whereby it was measured through the perceptions of respondents. This option is chosen because objective measure demands absolute information which is usually difficult to obtain given the fact that most firms do not provide absolute figures of their business performance. Recall that objective measures are concerned with absolute 
performance indicators while subjective measures are mainly concerned with the performance of a business in relation to its major competitors or relative to the company's expectations (wood and Robertson, 1997; Marvel, 2009; Olipia, 2006). Reliability analysis was performed in order to ensure the internal consistency and reliability of measures. Cronbach's alpha coefficient was calculated to confirm the reliability of the study constructs. The reliability coefficient obtained was 0.85 which exceeded the rule of thumb cut-off mark of 0.70 as suggested by Hatcher (1994), thereby confirming that the items are internally related to factors they are expected to measure.

\section{ANALYSIS AND RESULTS}

The dimensions of retail channel service: bulk-breaking, spatial convenience, waiting time, and product variety, were all regressed against the dependent variable which is customer retention. The aim was to ascertain if there is a significant relationship between these dimensions of retail channel service and customer retention. The regression values with related significant values are shown in the table below.

Table 1: Regression model summary

\begin{tabular}{|l|l|l|l|l|l|}
\hline Model & $\mathrm{R}$ & R square & Adjusted R Square & $\begin{array}{l}\text { Std. Error of the } \\
\text { estimate }\end{array}$ & Durbin-Watson \\
\hline 1 & $0.774^{\mathrm{a}}$ & 0.972 & 0.783 & 0.128 & 2.778 \\
\hline
\end{tabular}

a. Predictors: (Constant), BB, SC, WT, PV

b. Dependent Variable: CR

Table 2: The Regression Analysis on the Dimensions of Retail Channel Services and Customer Retention

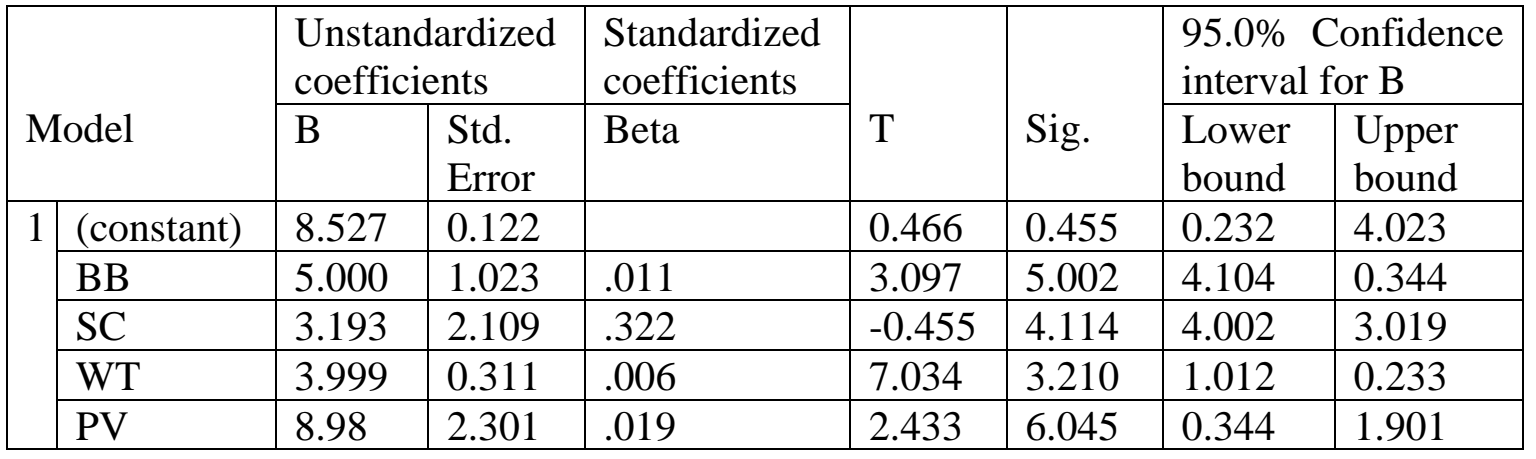

Dependent variable: Customer Retention 
International Journal of Entrepreneurship and Business Innovation

ISSN: 2689-9493

Volume 4, Issue 1, 2021 (pp. 96-108)

www.abjournals.org

Table 3: ANOVA Showing F-test

\begin{tabular}{|cl|l|l|l|l|l|}
\hline Model & & Sum of Squares & df & Mean Square & F & Sig. \\
\hline 1 & $\begin{array}{c}\text { Regression } \\
\text { Residual }\end{array}$ & 2134.167 & 4 & 355.694 & 3.177 & $2.440^{\mathrm{a}}$ \\
& Total & .000 & 23 & .000 & & \\
& 2134.167 & 29 & & & \\
\hline
\end{tabular}

a. Predictor: (Constant), BB, SC, WT, PV

b. Dependent Variable: CR

The data results of the regression are presented below:

$\mathrm{CR}=-8.527+5.000 \mathrm{BB}+3.193 \mathrm{SC}+3.999 \mathrm{WT}+8.98 \mathrm{PV}$

$\mathrm{Se}=(0.122)$

$\mathrm{T}=(0.466)$

$(\mathrm{ta} / 2=2.043)$

$\mathrm{R}^{2}=0.972$

$\mathrm{F}=3.177(\mathrm{fa}=2.45$ at 0.05 level of significance $)$

Std error $\left(8^{2}\right)=0.128$

Durbin-Watson (d) Statistic $=2.778$

(a) Statistical Interpretation

(i) Coefficient of determination $\left(\mathrm{R}^{2}\right)$ measures the percentage change in the dependent variable that is explained by the independent variables

(ii) T-test tests hold that if the values of independent variables are statistically significant, the rule of thumb is: reject $\mathrm{H}_{0}$ if $/ \mathrm{t} />{ }^{\mathrm{ta}} / 2$ at $5 \%$ level of significance, otherwise, accept $\mathrm{H}_{0}$

(iii) F-test tests the overall significance of the independent variables taken together. The rule of thumb is: reject $\mathrm{H}_{0}$ if $/ \mathrm{f} />\mathrm{fa}$ at a $5 \%$ level of significance and accept $\mathrm{H}_{1}$, otherwise, accept $\mathrm{H}_{0}$

(iv) Durbin-Watson (d) statistic helps to detect the presence of serial co-linearity of the first order among the variables used. The closer the (d) is to 2, the absence of serial co-linearity of the first order.

(v) Dependent Variable $=$ customer Retention (CR)

(vi) Independent Variable = Bulk Breaking (BB); Spatial Convenience (SC); waiting time (WT); Product Variety (PV)

(b) Evaluation of Regression Results 
The result shows that $\mathrm{R}^{2}=0.972$ which indicates that $97.2 \%$ of the changes in the dependent variable are explained by the changes in the independent variables. Further, the f-test shows that the variables are significant when taken together at a 5\% level of significance while the Durbin-Watson (d) statistic shows an absence of serial co-linearity of the first order at 2,778.

In addition,

$\mathbf{H}_{1}$ : the result shows that bulk breaking is positively related to customer retention. Therefore, a unit increase in bulk breaking increases customer retention by 5.000 and vice versa. Again, bulk breaking is statistically significant at a 0.05 level of significance. We, therefore, reject $\mathrm{H}_{01}$, and conclude that there is a significant relationship between bulk-breaking and customer retention.

$\mathbf{H}_{2}$ : The result revealed that there is a positive relationship between spatial convenience and customer retention. A unit change in spatial convenience positively affects customer retention by 3.913 and vice versa. The spatial convenience was also found to be statistically significant at a 0.05 level of significance. We, therefore, reject $\mathrm{H}_{02}$ and conclude that there is a significant relationship between Spatial Convenience and customer retention.

H3: The result revealed that there is a positive relationship between waiting time and customer retention. A reduction in waiting time increases customer retention by 3.999 and vice versa. Waiting time was also found to be statistically significant at a 0.05 level of significance. We, therefore, reject $\mathrm{H}_{03}$, and conclude that there is a significant relationship between waiting time and customer retention.

H4: The result also revealed that there is a positive relationship between product variety and customer retention. A percentage increase in product variety changes customer retention by 8.98 and vice versa. Product variety was also found to be statistically significant at a 0.05 level of significance. We, therefore, reject $\mathrm{H}_{04}$ and conclude that there is a significant relationship between product variety and customer retention.

\section{DISCUSSION OF FINDINGS}

Retailing shops or outlets play very crucial roles in the development of any economy, this is in view of the fact that the retail shops provide vast opportunities for the low-income earners who may not be able to afford to buy goods in bulk, to now buy goods required in little quantities as a result of bulk-breaking activities of these retail outlets.

The main objective of this work, therefore, was to study customer retention through retail channel service in physical chain stores in Nigeria. The intention of these authors, therefore, was to ascertain the extent to which the selected dimensions of retail channel service viz: bulkbreaking, spatial convenience, waiting time and product variety, will influence customer retention of the retail chain stores under study. The analysis of the data gathered from 135 retrieved out of 168 questionnaires distributed to respondents cutting across 56 retail chain stores revealed that retail channel service is significantly associated with customer retention. Consequently, the dimensions of retail channel service studied (i.e bulk-breaking, spatial convenience, waiting time and product variety), have a positive and significant influence on customer retention of retail chain stores in Nigeria. 
The outcome of our study thus concurs with the work of buckling (2004) who emphatically concluded that effective organization and control of retail channel service by retail firms is an active weapon to retaining satisfied customers and thus enhancing patronage. In the same vein, this finding also corroborates the findings of Ozuem et al (2008) who in their study concluded that customers value quick delivery, full assortment, bulk breaking and spatial convenience which can encourage or enhance customer retention. Our finding thus guides us in agreeing with lynching (2006) who argued that through retail channel service, organizations create a reputation that assures customers that they can be treated as truly valued customers and thereby enhancing chances of retaining customers which in turn guarantees the success of organizations.

\section{CONCLUSIONS AND IMPLICATIONS}

Consequent to the findings of our study which is based on the data analyzed, we are led to conclude that retail channel service has a positive and significant influence on customer retention of retail chain stores in Nigeria. In specific terms, bulk breaking, spatial convenience, waiting for time and product variety, positively correlated with customer retention of retail chain stores. The retail chain stores can thus, increase their customer base through a deliberate development of their retail channel service to suit the expectations of their customers. The implication, therefore, is that the retail chain stores, if effectively coordinated, and their marketing channel service properly managed, this is capable of enhancing the tendencies of these retail stores in retaining their existing customers.

\section{REFERENCES}

Ahmad R. and Buttle F. (2002). "Customer Retention Management - A Reflection of Theory and Practice: A Case Study," Marketing Intelligence and Planning, vol. 20, issue. 3, pp. 149-161.

Amit P. and Kameshvari B., (2012), "A Study on Consumer Behaviour of Organized and Unorganized Retail Outlets in Vadodara City" International Journal of Engineering and Management Sciences, Vol. 3, (4), pg 466-474.

Anderson E.W. and Sullivan M.W. (1993). "The Antecedents and Consequences of Customer Satisfaction for Firms," Marketing Science, vol. 12, issue. 2, pp. 125-143.

Arora N., (2012), "Introduction to Retail Industry"

Aydın K., (2013), "Perakende Yönetiminin Temelleri”, Nobel Yayını, 4. Basım.

Berry, L.L. and Parasuraman, A.Q. (1991) Marketing Services. New York: The Free Press.

Bucklin. L. T.(2004). A Theory of Distribution Channel Structure, Berkeley; Institute of Business and Economics Research, University of California.

Buttle, F. A. (2001) 'Customer retention: A potentially potent marketing management strategy',

Currah A. and Wrigley N. (2004). "Networks of Organizational Learning and Adaptation in Retail TNCs," Global Networks, A Journal of Transnational Affairs, vol. 4, issue. 1, pp. $1-23$

Dawkins, P.M. and Reichheld, F.F. (1990) 'Customer retention as a competitive weapon', Directors and Board, 14(summer), pp. 42-47. 
Dhotre, M. (2010), “Channel Management and Retail Marketing”, Himalaya Publishing House, Revised Edition. Enugu, Nigeria. A research dissertation. Ghavami, A. and Olyaei, A. (2006).

Ezenwanne, Y. N. (2005). A study of customer care practices in selected major supermarkets in Gallo, A. (2014) The Value of Keeping the Right Customers, Harvard Business Review.

Ghavami, A., \& Olyaei, A. (2006).The Impact of CFRM on customer retention (Master's Thesis, Lulea University of Technology).

Grönroos, C. (1990) 'Relationship approach to the marketing function in service contexts', Journal of Business Research, 29(1).

Jayaran, J., Vickery, S. and Droge, C. (2008). Relationship Building, Lean Strategy and Firm Performance: an Exploratory Study in the Automotive Supply Industry, International Journal of Production Research, 46 (20): 5633 - 49. Journal of Strategic Marketing, 9(1).

Kaliappan, S.R. Alavi, R. Abdullah K. and Zakaullah M.A. (2008). "Liberalization of Retail Sector and the Economic Impact of the Entry of Foreign Hypermarkets on Local Retailers in Saudi Arabia

Kim, M. Park, M and Jeong, D. (2004). "The Effects Of Customer Satisfaction and Switching Barrier on Customer Loyalty in Korean Mobile Telecommunication Services', Telecommunication Policy, Vol.28, Issue. 2, PP.323 - 342”.

Klang Valley, Malaysia," International Journal of Economics and Management, vol. 2, issue. 2, pp. $323-342$.

Kotler P. and Armstrong G., (2012), "Principles of Marketing”, Pearson Prentice Hall, 14th Edition.

Kotler, P. \& Armstrong, G. (2010) Principles of the marketing 11th edition. New York: Prentice-Hall International. USA.

Levy M. and Weitz A.B. (2009). Chapter 1 - Introduction to the World of Retailing, Retailing Management, 7th Edition, Erwin McGraw-Hill, China.

Lynch, R. (2006). Corporate Strategy, $4^{\text {th }}$ Edition, Harlow, Essex: Prentice-Hall, PP. 308 310.

Milli Eğitim Bakanlığ (MEB), (2008), "Pazarlama ve Perakende - Perakendeciliğin Özellikleri”, Ankara: MEGEP (Mesleki Eğitim ve Öğretim Sisteminin Güçlendirmesi Projesi”.

Mostart, P.G., Meyer, D \& Ransburg, L. R. J. (2009). The influence of service failure and service recovery on airline passenger's relationships with the domestic airline: an explanatory study. South African Business Review. 13 (2).

Mucuk I., (2009), "Pazarlama İlkeleri”, Türkmen Kitabevi, 17. Basım. Perakendecilik Noktalar1 [Online] . Available from: http://www.tml.web.tr/ konu-19.php, [Accessed 05 January 2016]

Oliver, R. L. (1997), Satisfaction: A Behavioural Perspective on the consumer. New York: McGraw Hills.

Oyeniyi, O. A. \& Abiodun, A. J. (2012) Measuring retail Service quality in Nigeria department stores. International Journal of Economic Behaviors. 2, 37-45.

Ozuem, W. Howel K. E. and Lancaster, G. (2008). Communicating in the New Interactive Marketplace. European Journal of Marketing, 42 (9 - 10): 1079.

Payne, A. and Frow, P. (1999) 'Developing a segmented service strategy: improving measurement in relationship marketing, Journal of Marketing Management, 15(8). 
Perreault W., Cannon J., McCarthy J., (2013), Pazarlamanın Temelleri:Biz Pazarlama Stratejisi Planlama Yaklaşımı”, Mc-Graw Hill, 13 Basımdan Çeviri (Nobel Yayını)

Rahman, A. U. and Masoom, M. R. (2012) 'Effects of Relationship Marketing on Customer Retention and Competitive Advantage: A Case Study on Grameen Phone Ltd.', Asian Business Review, 1(1).

Rajayogon, K. and Muthumani, S. (2015) 'The impact of demographic variables based on buying behaviour intentions towards e-store in India', Journal of theoretical and applied information Technology, 75(1), pp. 62-66.

Ramakrishnan, K. (2006). Customer retention: the key to business http://www.estrategicmarketing.com.smNovDec2/art11.html (Accesse1April 2010.)

Rana S.M.S, Osman A., \& Islam M.A (2014). Customer satisfaction of retail chain stores: evidence from Bangladesh. Journal of Asian Scientific Research, 4(10), 574-584.

Reichheld, F.F. and Sasser, W.E. (1990) 'Zero defections: Quality comes to services', Harvard Business Review, 68(5), pp. 105-111.

Reinartz W.J. and Kumar V. (1995). "The Impact of Customer Relationship Characteristics on Profitable Lifetime Duration," Journal of Marketing, vol. 67, issue. 1, pp. 77-99, 2003.

Rudrabasavaraj M. N., (2010), “Dynamic Global Retailing Management”, Himalaya Publishing House, 1st Edition.

Sekaran, U. (2003). Research Methods for Business. New York: John Wiley and Sons Inc.

Slater, F. S. (1997) Developing a customer value-based theory of the firm. Journal of the Academy of marketing sciences, 25(2), 162-167.

Vandermerwe, S. (1996) 'Becoming a customer “owning” corporation', Long Range Planning, 29(6). 